Bull. Fac. Agric., Cairo Univ., 66:114-129 (2015).

\title{
ECONOMICS OF MAJOR VEGETABLES GROWN IN GREEN HOUSES IN THE NEW LANDS
}

(Received: 13.5.2015)

\author{
By \\ G. M. Siam, A. M. Shahin* and E. S. S. Ali* \\ Agricultural Economics Department, Faculty of Agricultural, Cairo University \\ *Economics Studies Department, Desert Research Center
}

\begin{abstract}
The objectives of this research were to study the economics of green houses, through identifying constraints of production capacity and economic efficiency in Egypt in general, and studying the targeted vegetables crops in particular. It also targeted the financial assessment of these houses. The research also covered the cost and return and sensitivity to the dominant risks. This research relied on descriptive and quantitive economic analysis by using mathematic models from the perspective of the World Bank rules. This research is based on published secondary data from official establishments such as Ministry of Agriculture and CAPMAS. It also depended on data compiled from a form of random sample of about 130 green houses in Bahariya Oasises in 2014. It used sampling fraction about 3\% of cucumber, pepper and green beans houses with number of 50, 40 and 40 houses respectively. Some references and subject related studies were also studied.

Financial analysis reveals that all crops targeted by this study achieved production efficiency as profit gained was larger than opportunity cost. The most profitable crop was pepper, followed by green beans then cucumber. IRR of the three crops were $295 \%, 97 \%$ and $95 \%$, respectively. This indicates that the invested pound in cucumber, pepper and green beans in plastic house profits 0.95 , 2.95 and 0.97 pound, respectively. This is more than opportunity cost and achieves the economical efficiency. Payback period for the capital is estimated by about 1.06, 0.34 and 1.03 year, respectively.

The findings obtained suggested restoring the invested capital within less than a year for pepper and less than two years in the case of cucumber and green pepper. Based on what mentioned previously, economic feasibility of cucumber, pepper and green beans produced in houses is highly assured.
\end{abstract}

Key words: green houses, production, productivity, net present value (NPV), internal rate of return (IRR), sensitivity analysis.

\section{INTRODUCTION}

Food shortage problem is simply a result of the high rate of population growth. There is a wide gap between food supply and demand. This is why food shortage is regarded as a strategic issue at all levels. Adoption of modern technologies in agriculture becomes one of the most important agricultural development channels in supplying food. Protected agriculture is placed on top of technologies applied.

Protected agriculture is simply defined as a production system to produce high quality products out of their seasons of production. It depends on providing the relevant requirements of temperature and moisture in green or glass houses or tunnels. Such products are marketed all the year a round at high rates of prices (Korayem and Arram, 2010).

Recently, protected agriculture gains a larger share of attention because of its role in increasing food supply at large scales (El Abbasy et al., 2014). New lands and East Dalta are two of the most important areas for protected agriculture. In the meantime, areas of protected agriculture are regarded as an urban extension all over Egypt.

\subsection{Problem of the research}

The problem of this research is represented in the limited number of studies on the economics of protected agriculture especially green houses. Little attention directed to 
financial and economic assessment is also regarded as part of the problem. It is hoped that expansion of protected agriculture may contribute positively to declining the trade balance gap.

\subsection{Objectives of the research}

The objectives of this research were to study the economics of green houses, through identifying constraints of production capacity and economic efficiency in Egypt in general, and studying the targeted vegetables crops in particular. It also targeted the financial assessment of these houses. The research also covered cost and return and sensitivity to the dominant risks.

\section{MATERIAL AND METHODS}

This research was based mainly on descriptive and quantitative economic analysis using some statistical and mathematical models. This was mainly done to explain some variables related to the subject of this research. Financial and economic parameters issued by the World Bank were adopted to get profitability of the studied crops (El Abbasy et al., 2008). This research was based on published secondary data from official establishments such as the Ministry of Agriculture and CAPMAS. It also depended on data compiled from a form of random sample of about 130 green houses in Bahariya Oasises in 2014. It used sampling fraction about 3\% of cucumber, pepper and green beans houses with number of 50, 40, 40 houses respectively. Some references and subject related studies were also reviewed.

\section{RESULTS \& DISCUSSIONS 3.1. Economic importance of the studied crops}

Cucumber, pepper and green beans are very important vegetable crops, cucumber and pepper are consumed fresh, while green beans is consumed fresh or frozen, and they get a large share in Egyptian market. These crops can be exported in winter to areas like Europe and Arab States. The study examined constraints on the capacity of production of such crops to meet demand of important markets. It also, dealt with economical and financial evaluation of the chosen crops in the green houses.

3.1.1. First: Constraints of economic and production capacity

3.1.1.1. (A) Constraints of production and economic capacity for cucumber in Egypt
Major constraints of cucumber productivity are represented in the area of cucumber, yield/ feddan and total production. Table (1) showed evolution of the cultivated area during 20002012, as average area was estimated at about 67.71 thousand feddans. This area varies between increasing and decreasing, minority and majority of area reached $56.25,84.26$ thousand feddans in years 2001 and 2006, respectively. Public time trend showed a statistically significant upward trend, reaching 0.35 thousand feddans a year, with a change rate reaching about $0.52 \%$ from the average of cucumber area in the phase of the study. Time factor explains about $43.12 \%$ of the total changes in the total area of cucumber.

Table (1) also shows that yield per feddan during 2000-2012 reached about 8.97 tons. Productivity varied between increasing and decreasing, minority and majority of productivity reached $7.89,9.56$ tons in years 2001 and 2010 respectively. This is a statistically significant rising time trend, reaching 0.11 ton per year, with a change rate reaching about $1.23 \%$ from the average of cucumber productivity in the phase of the study. Time factor explains about $63.05 \%$ of the total changes in yield per feddan of cucumber.

Table (1) shows evolution of total production of cucumber during 2000 - 2012 indicating that average production reached about 608.61 thousand tons a year during the time span of this study. Production varied between increasing and decreasing, minority and majority of production reached 464.06, 802.64 thousand tons in years 2001 and 2006, respectively.

Equation of quadratic public time trend revealed a statistically significant upward trend, estimated at about 9.74 thousand tons a year, with change rate reaching $1.60 \%$ from the average of cucumber production in the phase of the study. Time factor explains about $59.50 \%$ of the total changes in cucumber production.

Major economic constraints on cucumber production are represented in both farm price and total returns. Data indicated that the average farm price reaching about L.E. 745 per ton. Farm price varies between increasing and decreasing. It reached its minority and majority of area reaching about L.E 526, 1233 per ton in years 2003 and 2012, respectively. Public time trend showed a statistically significant upward trend, reaching about L.E. 54.33 a year, with a change rate reaching about $7.29 \%$ from the average of cucumber farm price in the phase of 
Table (1): Statistical features of equations of public time trend for evolution of major constraints on productivity and economic constraints for cucumber in Egypt during (2000 - 2012).

\begin{tabular}{|c|c|c|c|c|c|c|c|c|c|c|c|}
\hline Items & Unit & \multicolumn{2}{|c|}{ Maximum } & \multicolumn{2}{|c|}{ Minimum } & Average & $\mathbf{R}^{2}$ & $\mathbf{F}$ & C.V & $\begin{array}{l}\text { Annual } \\
\text { Rate of }\end{array}$ & $\begin{array}{l}\text { Rate of } \\
\text { Change }\end{array}$ \\
\hline \multirow{2}{*}{ Area } & \multirow{2}{*}{ Feddan $_{(000)}$} & Area & 84.26 & Area & 56.25 & \multirow[t]{2}{*}{67.71} & \multirow{2}{*}{0.4312} & \multirow[t]{2}{*}{$3.79^{*}$} & \multirow{2}{*}{11.27} & \multirow[t]{2}{*}{$0.35^{(1)}$} & \multirow{2}{*}{0.52} \\
\hline & & Year & 2006 & Year & 2001 & & & & & & \\
\hline \multirow{2}{*}{ Yield } & \multirow{2}{*}{ Ton } & Yield & 9.56 & Yield & 7.89 & \multirow{2}{*}{8.97} & \multirow{2}{*}{0.6305} & \multirow{2}{*}{$18.77^{* * *}$} & \multirow{2}{*}{5.85} & \multirow{2}{*}{0.11} & \multirow{2}{*}{1.23} \\
\hline & & Year & 2010 & Year & 2000 & & & & & & \\
\hline \multirow{2}{*}{ Production } & \multirow{2}{*}{ Ton $_{(000)}$} & Production & 802.64 & Production & 464.06 & \multirow{2}{*}{608.61} & \multirow{2}{*}{0.5950} & \multirow{2}{*}{$7.34^{*}$} & \multirow{2}{*}{14.65} & \multirow{2}{*}{$9.74^{(1)}$} & \multirow{2}{*}{1.60} \\
\hline & & Year & 2006 & Year & 2001 & & & & & & \\
\hline \multirow{2}{*}{ Farm Prices } & \multirow{2}{*}{ LE/Ton } & Value & 1233 & Value & 526 & \multirow{2}{*}{745} & \multirow{2}{*}{0.8008} & \multirow{2}{*}{$44.21^{* * *}$} & \multirow{2}{*}{31.72} & \multirow{2}{*}{54.33} & \multirow{2}{*}{7.29} \\
\hline & & Year & 2012 & Year & 2003 & & & & & & \\
\hline \multirow{2}{*}{$\begin{array}{c}\text { Total } \\
\text { Returns }\end{array}$} & \multirow{2}{*}{$\mathbf{L E}_{(000)} / \mathrm{Ton}$} & Value & 11.68 & Value & 4.50 & \multirow{2}{*}{6.74} & \multirow{2}{*}{0.8683} & $\mathbf{7 2 . 5 2}^{* *}$ & 35.14 & 0.57 & 8.46 \\
\hline & & Year & 2012 & Year & 2003 & & & & & & \\
\hline
\end{tabular}

(1) Quadratic model.

Source: compiled and calculated by reference $(1,6)$. 
the study. Time factor explains about $80.08 \%$ of total changes of cucumber farm gate price. Table (1) also showed that the average of total return reached about L.E. 6.74 thousand feddans. Total returns evolutions varied between increasing and decreasing, minority and majority of the total returns reaching about L.E 4.50, 11.68 thousand in years 2003 and 2012, respectively. Equation of public time trend indicated a statistically significant upward trend, reaching about L.E. 570 yearly, with a change rate reaching about $8.46 \%$ from the average of cucumber total returns in the phase of the study. Time trend explains about $86.83 \%$ of the total changes in cucumber.

\subsubsection{2. (B) Constraints of productivity and} economic capacity of pepper in Egypt

Major constraints of productivity capacity of pepper are represented in cultivated area, yield/feddan and total production. Table (2) shows evolution of pepper area in Egypt during $2000-2012$. Average area of pepper reached about 85.77 thousand feddan over the period of the current study. This cultivated area varied between increasing and decreasing, minority and majority of the cultivated area reaching about 61.57, and 108.03 thousand feddans in 2001 and 2009, respectively. Equation of public time trend showed a statistically significant upward trend, reaching about 3.30 thousand feddans per year, with a change rate reaching about $3.84 \%$ from the average of pepper area in the phase of the study. Time factor explains about $71.18 \%$ of total changes in the total area of pepper.

Data in Table (2) show that the average yield per feddan reached about 6.80 tons. Productivity per feddan varied between increasing and decreasing with minimum and maximum about 6.28 , and 7.34 tons in years 2001 and 2009, respectively. Equation of public time trend shows a statistically significant upward trend, reaching about 0.06 ton per year, with a change rate reached $0.88 \%$ from the average of feddan productivity for pepper in the phase of the study. Time factor explains about $71.63 \%$ of the total changes in yield/feddan of pepper.

Data of Table (2) show the evolution of total production of pepper in Egypt 2000 - 2012. Average production reached about 587.81 thousand tons. In the study period, production varied between increasing and decreasing, minority and majority of production reaching about 386.69 , and 792.84 thousand tons in years 2001 and 2009 respectively. Public time trend equation shows a statistically significant upward trend, reaching about 27.87 thousand tons a year, with a change rate reaching about $4.74 \%$ from the average of pepper production in the study period. Time factor explains about 73.25 of the total changes in pepper production.

Major economic constraints on pepper production are represented in farm price and total returns. Average of farm price reaching about L.E. 920 per ton. Farm price varied between increasing and decreasing. It reached its minimum and maximum about L.E. 450, 1948 per ton in years 2000 and 2012 respectively. Equation of public time trend shows a statistically significant upward trend, reached about L.E. 136 a year, with change rate reaching about $14.75 \%$ from the average of pepper farm price in the phase of the study. Time factor explains about $77.99 \%$ of the total changes in farm price of pepper.

Data of Table (2) also shows that the average total returns reached about L.E. 6.37 thousand per feddan during the period of this research, returns varied between increasing and decreasing. It reached its minimum and maximum about L.E 2.90, 13.56 thousand per feddan in years 2000 and 2011 respectively. Equation of public time trend shows a statistically significant upward trend, reaching about L.E. 980 per year, with a change rate reaching about $15.38 \%$ from the average of pepper total returns in the phase of the study. Time trend explains about $78.95 \%$ of the total changes in the total returns of pepper.

\subsubsection{3. (C) Economic and productivity capacity constraints of green beans in Egypt}

Data of Table (3) show evolution of green beans area in Egypt during 2000 - 2012 showing that the average area reached about 59.16 thousand feddans. This area varied between increasing and decreasing reached its minimum and maximum about 50.72 and 73.02 thousand feddans in years 2001 and 2007, respectively. Equation of public time trend shows a statistically significant upward trend, reaching about 1.21 thousand feddans, with a change rate reaching about $2.05 \%$ from the average of green beans area in the study period. Time factor explains about $33.23 \%$ of the total changes in the total area of green beans.

The previous Table showed that the average yield per feddan during 2000-2012 reached about 4.44 tons. Productivity per feddan varied between increasing and decreasing. It reached 
Table (2): Statistical features of equations of public time trend for evolution of major constraints on productivity and economic constraints for pepper in Egypt during (2000 - 2012).

\begin{tabular}{|c|c|c|c|c|c|c|c|c|c|c|c|}
\hline Items & Unit & \multicolumn{2}{|c|}{ Maximum } & \multicolumn{2}{|c|}{ Minimum } & Average & $\mathbf{R}^{2}$ & $\mathbf{F}$ & C.V & $\begin{array}{l}\text { Annual } \\
\text { Rate of }\end{array}$ & $\begin{array}{l}\text { Rate of } \\
\text { Change }\end{array}$ \\
\hline \multirow{2}{*}{ Area } & \multirow{2}{*}{ Feddan $_{(000)}$} & Area & 108.03 & Area & 61.57 & \multirow{2}{*}{85.77} & \multirow{2}{*}{0.7118} & \multirow{2}{*}{$27.16^{* *}$} & \multirow{2}{*}{17.77} & \multirow{2}{*}{3.30} & \multirow{2}{*}{3.84} \\
\hline & & Year & 2009 & Year & 2001 & & & & & & \\
\hline \multirow{2}{*}{ Yield } & \multirow{2}{*}{ Ton } & Yield & 7.34 & Yield & 6.28 & \multirow{2}{*}{6.80} & \multirow{2}{*}{0.7163} & \multirow{2}{*}{$27.77^{* *}$} & \multirow{2}{*}{4.36} & \multirow{2}{*}{0.06} & \multirow{2}{*}{0.88} \\
\hline & & Year & 2009 & Year & 2001 & & & & & & \\
\hline \multirow{2}{*}{ Production } & \multirow{2}{*}{ Ton $_{(000)}$} & Production & 792.84 & Production & 386.69 & \multirow{2}{*}{587.81} & \multirow{2}{*}{0.7325} & \multirow{2}{*}{$30.12^{\text {** }}$} & \multirow{2}{*}{21.87} & \multirow{2}{*}{27.87} & \multirow{2}{*}{4.74} \\
\hline & & Year & 2009 & Year & 2001 & & & & & & \\
\hline \multirow{2}{*}{ Farm Prices } & \multirow{2}{*}{ LE/Ton } & Value & 1948 & Value & 450 & \multirow{2}{*}{920} & \multirow{2}{*}{0.7799} & \multirow{2}{*}{$38.99^{\text {** }}$} & \multirow{2}{*}{65.00} & \multirow{2}{*}{135.58} & \multirow{2}{*}{14.75} \\
\hline & & Year & 2012 & Year & 2000 & & & & & & \\
\hline \multirow{2}{*}{$\begin{array}{c}\text { Total } \\
\text { Returns }\end{array}$} & \multirow{2}{*}{$\mathbf{L E}_{(000)} /$ Ton } & Value & 13.56 & Value & 2.90 & \multirow{2}{*}{6.37} & \multirow{2}{*}{0.7895} & $41.25^{* *}$ & 67.79 & 0.98 & 15.38 \\
\hline & & Year & 2011 & Year & 2000 & & & & & & \\
\hline
\end{tabular}

Source: compiled and calculated from reference $(1,6)$. 
its minimum and maximum about 3.90 and 4.95 tons in years 2000 and 2006, respectively. Public time trend equation shows a statistically significant upward trend, reached about .02 ton, with a change rate reaching about $0.45 \%$ from the average of green beans productivity in the study period. Time factor explains about $54.72 \%$ of the total changes of yield per fed. for green beans.

Data of Table (3) show evolution of total production of green beans in Egypt during 2000 -2012. Average production reached about 261.10 thousand tons in the period of the study. Production varied between increasing and decreasing. It reached its minimum and maximum about 201.63 and 330.26 thousand tons in years 2000 and 2007, respectively. Public time trend shows a statistically significant upward trend, reaching about 5.84 thousand tons per year, with a change rate reaching about $2.24 \%$ from the average of green beans production in the phase of the study. Time factor explains about $39.89 \%$ of the total changes in green beans production.

Major economic constraints on green beans production are represented in farm price and total returns. Data of the previous Table show evolution of farm price of green beans during 2000 - 2012. Average of farm price reached about L.E. 955 per ton in the study period. Farm price varied between increasing and decreasing. It reached its minimum and maximum about L.E 497, and 2184 per ton in years 2001 and 2012, respectively. Public time trend shows a statistically significant upward trend, reaching about L.E. 128 per year, with a change rate reaching about $13.40 \%$ of average farm price of green beans in the phase of the study. Time factor explains about $83.79 \%$ of total changes in farm price.

From Table (3), it is clear that the average total returns reaching about L.E. 4.23 thousands per feddan during the period of the present study. Total returns vary between increasing and decreasing. It reached its minimum and maximum about L.E. 1.95 and 9.48 thousands tons in years 2000 and 2012, respectively. Public time trend equation shows a statistically significant upward trend, reaching L.E. 570 per year, with a change rate reaching about $13.47 \%$ from the average of green beans total returns in the phase of the study. Time factor explains about $87.66 \%$ of the total changes in total returns of green beans.

\subsubsection{Secondly: Constraints on the production capacity of plastic houses in Egypt}

Protected agriculture is one of the nontraditional agriculture to produce crops out of their season of production and to increase production. Philosophy of this pattern of agricultural production is based on controlling of climate circumstances, temperature, humidity and ventilation to meet crop requirements. Soil sterilization and adding fertilizers are adopted as well in this technique. In addition to food needs control. These investements in agriculture achieve big economic returns comparing with normal agriculture. Importance of economic protected agriculture represents in the change of agriculture map through increasing of local agriculture production with concentration on the most usage of natural resources. This nontraditional way of agriculture harmonizes with the Egyptian environment due to the current and future water poverty.

Number of green houses in Egypt reached about 40.12 thousands in 2004 - 2012. Green houses which accommodate cucumber, pepper and green beans reaching about 36.47 thousands. Cucumber was ranked first with 21.54 thousands followed by 8.04 thousands and green beans 6.89 thousands green houses. Comparative importance for the three crops was $53.69 \%, 20.04 \%$ and $17.17 \%$ respectively (MALR, 2004 - 2012).

Data of Table (4) shows evolution of area of green houses, number of plastic houses and total production in Egypt 2004 - 2012. Average area of houses reached about 17412 thousands square meter during the period of the study. This area increased from 10269 thousand square meter in 2004 to about 30196 thousand square meter in 2012. Public time trend equation shows a statistically significant upward trend, reaching about 2026 thousand square meter per year, with change rate reaching about $11.63 \%$ from the average of area of green houses in the phase of the study. Time factor explains about $76.03 \%$ of total changes in the total area of green houses.

Data of the previous Table show that the average number of greenhouses reached about 40.12 thousand houses during 2004-2012. The number increased from 24.76 thousand houses in 2004 to about 61.25 thousands in 2012. Public time trend equation shows a statistically significant upward trend, reaching about 3.85 thousand houses per year, with a change rate reaching about $9.60 \%$ from the average of 
Table (3): Statistical features of equations of public time trend for evolution of major constraints on the productivity and economic constraints for green beans in Egypt during (2000 - 2012).

\begin{tabular}{|c|c|c|c|c|c|c|c|c|c|c|c|}
\hline Items & Unit & \multicolumn{2}{|c|}{ Maximum } & \multicolumn{2}{|c|}{ Minimum } & Average & $\mathbf{R}^{2}$ & $\mathbf{F}$ & C.V & $\begin{array}{l}\text { Annual } \\
\text { Rate of }\end{array}$ & $\begin{array}{c}\text { Rate of } \\
\text { Change }(\%)\end{array}$ \\
\hline \multirow{2}{*}{ Area } & \multirow{2}{*}{$\begin{array}{c}\text { Feddan } \\
(000)\end{array}$} & Area & 73.02 & Area & 50.72 & \multirow{2}{*}{59.16} & \multirow{2}{*}{0.3323} & \multirow{2}{*}{$5.447 *$} & \multirow{2}{*}{13.77} & \multirow{2}{*}{1.21} & \multirow{2}{*}{2.05} \\
\hline & & Year & 2007 & Year & 2001 & & & & & & \\
\hline \multirow{2}{*}{ Yield } & \multirow{2}{*}{ Ton } & Yield & 4.95 & Yield & 3.90 & \multirow{2}{*}{4.44} & \multirow{2}{*}{0.5472} & \multirow{2}{*}{$6.04 *$} & \multirow{2}{*}{6.62} & \multirow{2}{*}{$0.02(1)$} & \multirow{2}{*}{0.45} \\
\hline & & Year & 2006 & Year & 2000 & & & & & & \\
\hline \multirow{2}{*}{ Production } & \multirow{2}{*}{ Ton $(000)$} & Production & 330.26 & Production & 201.63 & \multirow{2}{*}{261.10} & \multirow{2}{*}{0.3989} & \multirow{2}{*}{$7.30 *$} & \multirow{2}{*}{13.79} & \multirow{2}{*}{5.84} & \multirow{2}{*}{2.24} \\
\hline & & Year & 2007 & Year & 2000 & & & & & & \\
\hline \multirow{2}{*}{$\begin{array}{l}\text { Farm } \\
\text { Prices }\end{array}$} & \multirow{2}{*}{ LE/Ton } & Value & 2184 & Value & 497 & \multirow{2}{*}{955} & \multirow{2}{*}{0.8379} & \multirow{2}{*}{$56.86^{* * *}$} & \multirow{2}{*}{56.92} & \multirow{2}{*}{128} & \multirow{2}{*}{13.40} \\
\hline & & Year & 2012 & Year & 2001 & & & & & & \\
\hline \multirow{2}{*}{$\begin{array}{c}\text { Total } \\
\text { Returns }\end{array}$} & \multirow{2}{*}{$\begin{array}{c}\text { LE } \\
(000) / \text { Ton }\end{array}$} & Value & 9.48 & Value & 1.95 & \multirow{2}{*}{4.23} & \multirow{2}{*}{0.8766} & $7017 \%$ & 5576 & $0=7$ & 12 \\
\hline & & Year & 2012 & Year & 2000 & & & $8.1 / .0$. & $35 . / 0$ & 0.51 & $15.4 /$ \\
\hline
\end{tabular}

(1) Quadratic model.

Source: compiled and calculated from reference $(1,6)$ 
number of greenhouses in the phase of the study. Time factor explains about $82.81 \%$ of total agricultural houses.

Data of Table (4) show evolution of the total production of green houses in Egypt during 2000 - 2012. Average production reaching about 176.34 thousand tons. Production varied between increasing and decreasing. It reached its minority and majority about 96.07 and 271.31 thousand tons in years 2004 and 2012, respectively. Public time trend equation shows a statistically significant upward trend, reached about 15.90 thousand tons a year, with change rate reaching about $9.02 \%$ from the average of total production for the green houses in the study period. Time factor explains about $66.39 \%$ of the total changes in total production of green houses.

\subsubsection{1. (A) Constraints of cucumber production capacity in green houses}

Data of Table (4) show evolution of each of area, number of houses, productivity and total production of plastic houses cucumber in Egypt during 2004-2012. Average area of cucumber houses reached around 8239 thousand square meters during the period of this study. Cucumber area increased from 5396 thousand square meter in 2004 to 13138 thousand square meters in 2012. Public time trend equation showed a statistically significant upward trend, reaching 830 thousand square meters a year, with a change rate reaching about $10.07 \%$ from the average of total area from cucumber green houses in Egypt during the study period. Time factor explains about $70.51 \%$ of the total changes in houses of cucumber in Egypt.

Data of the previous Table show that the average number of cucumber green houses in Egypt reached about 21.54 thousands during 2004-2012. This number increased from 14.29 thousands in 2004 to 33.22 thousands in 2012. Public time trend equation shows a statistically significant upward trend, reaching about 2.24 thousands per year, with a change rate reaching about $10.40 \%$ from the average of cucumber green houses in Egypt during the study period. Time factor explains about $76.05 \%$ of the total number of cucumber green houses in Egypt.

Data of the previous Table show that average productivity of cucumber grown in green houses in Egypt reached about $12.23 \mathrm{~kg}$. /square meter during $2004-2012$. Productivity of one green house varied between increasing and decreasing. It reached its minority and majority about 9.84 and $14.92 \mathrm{~kg}$. /square meter in 2011 and 2007, respectively. Public time trend equation shows a statistically significant upward diminishing trend, reached $0.19 \mathrm{~kg}$. /square meter per year. Time factor explains about $73.52 \%$ of total changes of productivity of cucumber green houses in Egypt.

Data of Table (4) show evolution of total production of houses cucumber during 20002012. Average production reached 99.55 thousand tons during the period of the study. Production varied between increasing and decreasing. It reached its minority and majority about 60.05 and 139.43 thousand tons in 2004 and 2012, respectively. Public time trend equation shows a statistically significant upward trend, reaching about 7.39 thousand tons a year, with change rate reaching about $7.43 \%$ from the average production of cucumber houses in the study period. Time factor explains about $45.60 \%$ of the total changes in cucumber production produced in green houses.

\subsubsection{2. (B) Constraints of production capacity for pepper produced in green houses in Egypt \\ Data of Table (4) show evolution of areas,} number of houses, productivity and total production in Egypt 2004 - 2012. Average area of pepper produced in houses in Egypt reaching about 3846 thousand square meters during the period of the study. This area varied from 1754 thousand square meters in 2004 to be 9884 thousand square meters in 2012. Public time trend equation shows a statistically significant upward trend, reaching about 739 thousand square meter a year, with a change rate reaching about $19.21 \%$ from the average of the total area for pepper houses in the period of the study. Time factor explains about $66.06 \%$ of total changes in the area of pepper produced in houses in Egypt.

Data of the previous Table show that the average number of houses producing pepper reached about 8.04 thousand houses during 2004-2012. Number of houses increased from 3.74 thousands in 2004 to 15.49 thousands in 2012. Public time trend equation shows a statistically significant upward trend, reaching about 1.18 thousand houses per year, with a change rate reaching about $14.68 \%$ from the average of pepper houses number in the time of study. Factor of time explains about $81.74 \%$ from the total number of pepper houses in Egypt.

Data of the previous Table show that the average productivity of pepper houses in Egypt 
Table (4): Statistical features of equations of public time trend for the evolution of major constraints on productivity constraints for total houses and each of cucumber, pepper and green beans in Egypt during (2000-2012).

\begin{tabular}{|c|c|c|c|c|c|c|c|c|c|c|c|c|}
\hline \multicolumn{2}{|c|}{ Items } & \multirow{3}{*}{$\begin{array}{c}\text { Unit } \\
\begin{array}{c}\text { Thousand } \\
\text { meters2 }\end{array}\end{array}$} & \multicolumn{2}{|c|}{ Maximum } & \multicolumn{2}{|c|}{ Minimum } & \multirow{3}{*}{$\begin{array}{c}\text { Average } \\
\\
8239\end{array}$} & \multirow{3}{*}{$\begin{array}{c}\mathbf{R}^{2} \\
0.7051\end{array}$} & \multirow{3}{*}{$\begin{array}{c}\mathbf{F} \\
16.74 * *\end{array}$} & \multirow{3}{*}{$\begin{array}{r}\text { C.V } \\
32.85\end{array}$} & \multirow{3}{*}{$\begin{array}{c}\text { Annual } \\
\text { Rate of } \\
\text { Change } \\
830\end{array}$} & \multirow{3}{*}{$\begin{array}{c}\text { Rate of } \\
\text { Change(\%) } \\
10.07\end{array}$} \\
\hline \multirow{8}{*}{ 己ٍ } & \multirow[t]{2}{*}{ Area } & & Area & 13138 & Area & 5396 & & & & & & \\
\hline & & & Year & 2012 & Year & 2004 & & & & & & \\
\hline & Number of & \multirow{2}{*}{ Thousand } & Number & 33.22 & Number & 14.29 & \multirow{2}{*}{21.54} & \multirow{2}{*}{0.7605} & \multirow{2}{*}{$22.22 * *$} & \multirow{2}{*}{32.63} & \multirow{2}{*}{2.24} & \multirow{2}{*}{10.40} \\
\hline & greenhouses & & Year & 2012 & Year & 2004 & & & & & & \\
\hline & \multirow[t]{2}{*}{ Yield } & \multirow[t]{2}{*}{ kg/meter2 } & Yield & 14.92 & Yield & 9.84 & \multirow[t]{2}{*}{12.23} & \multirow[t]{2}{*}{0.7352} & \multirow[t]{2}{*}{$8.33 * *$} & \multirow[t]{2}{*}{13.65} & \multirow[t]{2}{*}{$-0.19(1)$} & \multirow[t]{2}{*}{-1.55} \\
\hline & & & Year & 2007 & Year & 2011 & & & & & & \\
\hline & Production & Thousand & Production & 139.43 & Production & 60.05 & 99.55 & 0.4560 & $5.96 *$ & 30.00 & 7.39 & 7.43 \\
\hline & & tons & Year & 2012 & Year & 2004 & & & & & & \\
\hline & Area & Thousand & Area & 9884 & Area & 1754 & 3846 & 0.6606 & $13.63 * *$ & 64.78 & 739 & 19.21 \\
\hline & & & Year & 2012 & Year & 2004 & & & & & & \\
\hline & Number of & Thousand & Number & 15.49 & Number & 3.74 & 8.04 & 0.8174 & $31.33 * *$ & 44.32 & 1.18 & 14.68 \\
\hline & greenhouses & & Year & 2012 & Year & 2004 & & & & & & \\
\hline 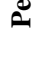 & Yield & kg/meter2 & Yield & 10.35 & Yield & 7.75 & 9.23 & 0.7502 & $9.01 * *$ & 10.57 & $-0.07(1)$ & -0.76 \\
\hline & & & Year & 2007 & Year & 2004 & & & & & & \\
\hline & Production & Thousand & Production & 83.16 & Production & 13.60 & 34.92 & 0.6469 & $12.82 * *$ & 59.18 & 6.07 & 17.38 \\
\hline & & tons & Year & 2012 & Year & 2004 & & & & & & \\
\hline & Area & Thousand & Area & 4525 & Area & 1829 & 3292 & 0.6394 & $12.41 * *$ & 29.20 & 281 & 8.52 \\
\hline & & & Year & 2012 & Year & 2004 & & & & & & \\
\hline & Number of & Thousand & Number & 8.79 & Number & 4.01 & 6.89 & 0.5381 & 8.16* & 23.70 & 0.44 & 6.39 \\
\hline 巳一 & greennouses & & Year & 2010 & Year & 2004 & & & & & & \\
\hline U⿺辶大 & Yield & kg/meter2 & Yield & 6.74 & Yield & 5.91 & 6.29 & - & - & 4.48 & 0.003 & 0.05 \\
\hline & & & Year & 2005 & Year & 2008 & & & & & & \\
\hline & Production & Thousand & Production & 29.17 & Production & 11.02 & 20.69 & 0.6473 & $12.84 * *$ & 29.01 & 1.76 & 8.51 \\
\hline & & tons & Year & 2012 & Year & 2004 & & & & & & \\
\hline & Area & Thousand & Area & 30196 & Area & 10269 & 17412 & 0.7603 & $22.20 * *$ & 36.54 & 2026 & 11.63 \\
\hline & & & Year & 2012 & Year & 2004 & & & & & & \\
\hline స్త్ర & Number of & Thousand & Number & 61.25 & Number & 24.76 & 40.12 & 0.8281 & $33.71 * *$ & 40.12 & 3.85 & 9.60 \\
\hline & & & Year & 2012 & Year & 2004 & & & & & & \\
\hline & Production & Thousand & Production & 271.31 & Production & 96.07 & 176.34 & 0.6639 & $13.82 * *$ & 30.31 & 15.90 & 9.02 \\
\hline & & & Year & 2012 & Year & 2004 & & & & & & \\
\hline
\end{tabular}

${ }^{(1)}$ Quadratic model.

(Area: Thousand meters ${ }^{2}$, Yield: kg/meter ${ }^{2}$, Production: Thousand tons)

Source: compiled and calculated from reference $(1,6)$. 
reached about $9.23 \mathrm{~kg} / \mathrm{square}$ meters during 2004 - 2012. House productivity varied between increasing and decreasing. It reached its minority and majority about 7.75 and $10.35 \mathrm{~kg}$. /square meter in 2004 and 2007, respectively. Public time trend equation showed a statistically significant diminishing trend, reaching about $0.07 \mathrm{~kg}$. /square meter per year, with change rate reaching about $-0.76 \%$ from the average of productivity of pepper house in the study period. Time factor explains about $75.02 \%$ of the total changes in pepper houses productivity in Egypt.

Data of Table (4) show the evolution of total production from pepper houses during 2000 2012. Average production reached about 34.92 thousand tons during the period of the study, production varied between increasing and decreasing. It reached its minority and majority about 16.60 and 83.16 thousand tons in 2004 and 2012, respectively. Public time trend equation showed a statistically significant upward trend, reaching about 6.07 thousand tons per year, with a change rate reaching about $17.38 \%$ from the average production of pepper houses in this period of the study. Time factor explains about $64.69 \%$ of the total changes of pepper produced of in houses in Egypt.

\subsubsection{3.(C) Constraints on the productivity capacity for green beans in green houses}

Data of Table (4) refer to the evolution of areas, number of houses, productivity and total production from houses of green beans in Egypt during $2004-2012$. Average of area of green beans houses reached about 3292 thousand square meters through the study period. Area of houses increased 1829 thousand square meter in 2004 to about 4525 thousands square meter in 2012. Public time trend equation shows a statistically significant upward trend, reaching about 281 thousands square meter per year, with a change rate reaching about $8.52 \%$ from the average of the total area of green beans houses in the study period. Time factor explains about $63.94 \%$ of total variables in the area of green beans houses in Egypt.

Data of the previous Table show that the average number of green beans houses in Egypt reached about 6.89 thousand houses during 2004 - 2012. Number of green houses varied between increasing and decreasing. Its minimum and maximum reaching about 4.01 and 8.79 thousand houses in 2004 and 2010, respectively. Public time trend showed a statistically significant upward trend, reaching about 0.44 thousand houses per year, with a change rate reaching about $6.39 \%$ from the average number of green beans houses in the period of this study. Time factor explains about 53.81 of the total green beans green houses in Egypt.

Data of the previous Table show that the average productivity of green beans plastic house reached about $6.29 \mathrm{~kg}$./square meter during 2004-2012. A plastic house productivity varied between increasing and decreasing. Its minimum and maximum reaching about 5.91 and $6.74 \mathrm{~kg}$. /square meter in 2008 and 2005 , respectively. Public time trend equation shows an upward trend, statistically insignificant reaching about $0.003 \mathrm{~kg}$. /square meter per year with a change rate reached $0.05 \%$ of the average productivity of green beans productivity for each green house.

Data of Table (4) show the evolution of the total production of green houses during 20002012. Average production reached about 20.69 thousand tons during the period of this study. Production varied between increasing and decreasing. Its minimum and maximum reaching about 11.02 and 29.17 thousand tons in 2004 and 2012, respectively. Public time trend equation showed a statistically significant upward trend, reaching about 1.76 thousand tons per year with a change rate reaching about $8.51 \%$ of the average production of green beans in Egypt. Time factor explains about $64.69 \%$ of the total changes of green beans produced in green houses in Egypt.

\subsubsection{Comparative production efficiency for plastic houses compared with traditional agriculture}

Comparative productivity efficiency for cucumber, pepper and green beans produced in houses compared with their counter parts of uncovered agriculture during 2004 - 2012. Data of Table (5) showed that the productivity efficiency in houses was higher than traditional agriculture for the three crops by percentages of $349.24 \%, 350.29 \%$ and $248.46 \%$, respectively. because the greenhouses provide the necessary requirements for growth, through controlling of climatic circumstances such as temperature, moister, ventilation and ability of soil preparation with sterilizing or adding of fertilizers, swell as controlling of food needs. This causes increasing of productivity for area unit. 
Table (5): Comparative productivity importance in green houses compared with their counter parts in traditional agriculture for cucumber, pepper and green beans in Egypt (2004-2012).

\begin{tabular}{|c|c|c|c|c|}
\hline Items & Unit & Cucumber & Pepper & Green Beans \\
\hline Square meter productivity & kg/meter ${ }^{2}$ & 12.23 & 9.23 & 4.29 \\
\hline Greenhouse productivity & Ton/greenhouse & 2.94 & 2.21 & 1.03 \\
\hline $\begin{array}{l}\text { Feddan productivity (Protected } \\
\text { agriculture) }\end{array}$ & Ton & 32.34 & 24.31 & 11.33 \\
\hline $\begin{array}{l}\text { Feddan productivity (traditional } \\
\text { agriculture) }\end{array}$ & Ton & 9.26 & 6.94 & 4.56 \\
\hline Comparative production efficiency & $\%$ & 349.24 & 350.29 & 248.46 \\
\hline
\end{tabular}

${ }^{(1)}$ Each feddan accommodates (10-12) houses at an average of eleven houses. Area of each green house is estimated by 6 meter $x 40$ meter.

Source: compiled and calculated based on Tables (1-4).

\subsubsection{Thirdly: Economics of green houses with respect to the crops covered by this study}

Protected agriculture is a modern technique to increase production to bridge the food gap. This technique is of great importance in arid and semi-arid lands which cover vast areas in Egypt. Protected agriculture has many advantages as minimizing damages that may be caused by bad weather conditions and also allows more intensification practices. Protected agriculture also prevents the growth of bad weeds which make work easier.

As a result of over population and need for food, it became very important to pay attention to develop non-traditional agriculture (protected agriculture), to achieve self-sufficiency and national economy support. This can be achieved through economical and financial analysis for protected houses, and through identifying of investment opportunities for this investment industry in the agricultural field (Hassan and Mohamed, 2009).

\subsubsection{1. (A) Investment costs of green houses}

Data of Table (6) showed comparative importance of investment cost items for the three crops targeted by this study. Value of investment items reaching about L.E. 5.58 thousands representing about $69.47 \%$ of total costs. This shows the comparative importance for fixed capital in protected agriculture comparing with costs of variable capital. Comparative importance for each of the value of construction and machines revolve around $90.67 \%$ and $9.33 \%$, respectively. Average cost of each of metal structure and plastic cover is ranked as the first and second, as their importance reaching about $59.23 \%$ of the total investment cost of green houses.

\subsubsection{2. (B) Estimate of operating cost}

Data of Table (7) refer to the comparative importance of operating cost items per year for cucumber, pepper and green beans. Value of chemical fertilizers, temporary labor, seeds, pesticides and feeders reaching about L.E. 1.60 thousands representing about $65.31 \%$ of the total costs of operation per year for cucumber. Value of chemical fertilizers, wages of temporary labor, pesticides, fertilizer, feeder and cost of transport reaching about L.E. 1.80 thousands representing about $67.92 \%$ of total costs of operation per year for pepper. Value of chemical fertilizers, wages of temporary labor and pesticides reaching about L.E. 1.70 thousands representing about $61.82 \%$ of total costs of operation per year for green beans. 
Table (6): Comparative importance of average investment cost of green houses producing cucumber, pepper and green beans.

\begin{tabular}{|l|c|c|c|c|c|c|}
\hline \multirow{2}{*}{ Costs Items } & \multicolumn{2}{|c|}{ Cucumber } & \multicolumn{2}{c|}{ Pepper } & \multicolumn{2}{c|}{ Green Beans } \\
\cline { 2 - 7 } & $\begin{array}{c}\text { Value } \\
\text { (L E) }\end{array}$ & $\%$ & $\begin{array}{c}\text { Value } \\
\text { (L E) }\end{array}$ & $\%$ & $\begin{array}{c}\text { Value } \\
\text { (L E) }\end{array}$ & $\%$ \\
\hline A) Construction Value & 5056 & 90.67 & 5056 & 90.67 & 5056 & 90.67 \\
\hline 1- Land & 250 & 4.48 & 250 & 4.48 & 250 & 4.48 \\
\hline 2- Soil and Water Analysis & 10 & $\mathbf{0 . 1 8}$ & 10 & $\mathbf{0 . 1 8}$ & 10 & 0.18 \\
\hline 3- Soil Create & 200 & 3.59 & 200 & 3.59 & 200 & 3.59 \\
\hline 4- Metal Structures & 2100 & 37.66 & 2100 & 37.66 & 2100 & 37.66 \\
\hline 5- Plastic Covers & 1203 & 21.57 & 1203 & 21.57 & 1203 & 21.57 \\
\hline 6- Wire/Cable to Flatten & 263 & 4.72 & 263 & 4.72 & 263 & 4.72 \\
\hline 7- Doors & 240 & 4.30 & 240 & 4.30 & 240 & 4.30 \\
\hline 8- Greenhouses Assembly Costs & 220 & 3.95 & 220 & 3.95 & 220 & 3.95 \\
\hline 9- Fibers & 200 & 3.59 & 200 & 3.59 & 200 & 3.59 \\
\hline 10- Buildings & 170 & 3.05 & 170 & 3.05 & 170 & 3.05 \\
\hline 11- Other ${ }^{(1)}$ & 200 & 3.59 & 200 & 3.59 & 200 & 3.59 \\
\hline B) Machines and Equipment & 520 & 9.33 & 520 & 9.33 & 520 & 9.33 \\
\hline 1- Irrigation net & 200 & 3.59 & 200 & 3.59 & 200 & 3.59 \\
\hline 2- Water Pumps & 100 & 1.79 & 100 & 1.79 & 100 & 1.79 \\
\hline 3- Spraying and Control Motors & 200 & 3.59 & 200 & 3.59 & 200 & 3.59 \\
\hline 4- Irrigation net Assembly wage & 20 & 0.36 & 20 & 0.36 & 20 & 0.36 \\
\hline Investment Costs & 5576 & 100.00 & 5576 & 100.00 & 5576 & 100.00 \\
\hline
\end{tabular}

(1) This includes transport of metal structures and plastic covers.

Source: questionnaire data.

Table (7): Comparative importance of average cost of annual operation of green houses producing cucumber, pepper and green beans.

\begin{tabular}{|l|c|c|c|c|c|c|}
\hline \multirow{2}{*}{ Costs Items } & \multicolumn{2}{|c|}{ Cucumber } & \multicolumn{2}{c|}{ Pepper } & \multicolumn{2}{c|}{ Green Beans } \\
\cline { 2 - 7 } & $\begin{array}{c}\text { Value } \\
(\text { L E })\end{array}$ & $\%$ & $\begin{array}{c}\text { Value } \\
\text { (L E) }\end{array}$ & $\%$ & $\begin{array}{c}\text { Value } \\
(\text { L E })\end{array}$ & \multirow{2}{*}{} \\
\hline 1- Seeds and Seedlings & 300 & 12.24 & 200 & 7.55 & 200 & 7.27 \\
\hline 2- Seeds Incubated & 50 & 2.04 & 50 & 1.89 & 50 & 1.82 \\
\hline 3- Agri., Mechanization Processes & 70 & 2.86 & 70 & 2.64 & 70 & 2.55 \\
\hline 4- Organic Fertilizer & 200 & 8.16 & 200 & 7.55 & 200 & 7.27 \\
\hline 5- Chemical Fertilizer & 500 & 20.41 & 600 & 22.64 & 600 & 21.82 \\
\hline 6- Permanent Labor Wages & 80 & 3.27 & 80 & 3.02 & 80 & 2.91 \\
\hline 7- Temporary Labor Wages & 500 & 20.41 & 500 & 18.87 & 600 & 21.82 \\
\hline 8- Pesticides, Fertilizer, Feeder & 300 & 12.24 & 400 & 15.09 & 500 & 18.18 \\
\hline 9- Maintenance & 150 & 6.12 & 150 & 5.66 & 150 & 5.45 \\
\hline 10- Transport Cost & 200 & 8.16 & 300 & 11.32 & 200 & 7.27 \\
\hline 11- Other & 100 & 4.08 & 100 & 3.77 & 100 & 3.64 \\
\hline Operation Costs & 2450 & 100.00 & 2650 & 100.00 & 2750 & 100.00 \\
\hline
\end{tabular}

Source: questionnaire data. 


\subsubsection{3. (C) Estimates of total returns}

Data of Table (8) showed that the average production of cucumber in houses reached about 4.56 tons, valued at L.E. 7.98 thousands. Average production of pepper reached about 2.64 tons, valued at L.E. 21.12, 253.44 thousands for each house and feddan, respectively. Average production of green beans in houses reached about 1.20 tons valued at L.E. $8.40,100.80$ thousands for each house and feddan, respectively. analysis results were deduced. Data of Table (9) showed that current net return at $10 \%$ discount for the three crops reaching about 21.34, 79.04 and 21.97 (thousands LE.), respectively. Cost/ benefit ratio at $10 \%$ discount for the three crops reaching about 2.04, 4.68 and 2, respectively. IRR rate reached about $95 \%, 295 \%$ and $97 \%$, respectively. This indicates that the invested pound in cucumber, pepper and green beans in plastic house profits $0.95,2.95$ and 0.97 pound, respectively. This is more than opportunity cost

Table (8): Average value of production for plastic house, producing cucumber, pepper green beans.

\begin{tabular}{|l|l|c|c|c|}
\hline \multicolumn{1}{|c|}{ Statement } & Unit & Cucumber & Pepper & Green Beans \\
\hline Average Production & (Ton/House green) & 4.56 & 2.40 & 1.20 \\
\hline Average Prices & (LE/Ton) & 1750 & 8000 & 7000 \\
\hline Production Value & (Thousand LE/ House green) & 7.98 & 19.20 & 8.40 \\
\hline
\end{tabular}

Source: questionnaire data.

3.1.4. Fourthly: Financial analysis of the studied crops produced in green houses

Financial analysis depends on a set of hypothesis that matches with economic logic which suggests that the time span of any project is 10 years. Replacement of plastic covers takes place in the fourth year with a discount rate $10 \%$. Replacement of irrigation network in the sixth year as its expiry date is 5 years only.

By using mathematical relation between current values of returns and costs, financial and achieves the economical efficiency. Payback period for the capital is estimated by about $1.06,0.34$ and 1.03 year, respectively.

These obtained findings suggest restoring the invested capital within less than a year for pepper and less than two years in the case of cucumber and green pepper. Based on what mentioned previously, economic feasibility of cucumber, pepper and green beans produced in houses is highly assured.

Table (9): Results of financial analysis of green houses producing cucumber, pepper and and green beans.

\begin{tabular}{|c|c|c|c|c|}
\hline Financial Analysis Indicators & Unit & Cucumber & Pepper & Green Beans \\
\hline Present Value of Benefits (PVB) $)^{(1)}$ & (Thousand LE) & 41.78 & 100.52 & 43.98 \\
\hline Present Value of Costs (PVC) ${ }^{(1)}$ & (Thousand LE) & 20.44 & 21.48 & 22.01 \\
\hline Net Present Value (NPV) ${ }^{(1)}$ & (Thousand LE) & 21.34 & 79.04 & 21.97 \\
\hline Benefit/Cost (B/C) & (Ratio) & 2.04 & 4.68 & 2 \\
\hline Internal rate of return (IRR) & $(\%)$ & 95 & 295 & 97 \\
\hline Pay Back Period (p.b.p) & (Year) & 1.06 & 0.34 & 1.03 \\
\hline
\end{tabular}

(1) Discount Rate 10\%.

Source: results of the analysis by cost been program based on Tables (6-8). 


\subsubsection{Sensitivity analysis}

Projects seem more feasible as long as they stay less sensitive to changes of costs and total returns. Table (10) shows results of sensitivity analysis of green houses producing cucumber, pepper and green beans through raising costs by $20 \%, 40 \%$ and $60 \%$ on one side, and returns decline by $20 \%$ and $40 \%$ from the other side. In addition to analyzing the returns of raising costs and returns decline by $20 \%$ and $30 \%$, respectively.

Findings also show that plastic houses look feasible financially. Impact of return changes is bigger than the impact of total cost changes. Plastic houses remain feasible in the case of returns decline and total costs rise to $30 \%$ as IRR were $21 \%, 135 \%$ and $19 \%$ for cucumber, pepper and green beans, which is higher than discount coefficient and opportunity cost which is $10 \%$. demand, food shortage is seriously seen as a strategic issue at all levels. From this standpoint, adoption of modern technologies becomes inevitable. Protected agriculture is actually one of these applied technologies, used for filling this food gap and for solving many agricultural problems in Egypt. Protected agriculture is simply defined as a production system for producing high quality products out of traditional seasons of production. This new technique depends upon providing relevant requirements of temperature and moisture in plastic or glass houses or tunnels. Economic production risk is mostly reduced as crop requirements are met safely. Recently, much attention has been given to protected agriculture in the new lands in particular. This attention is increasing steadily because protected agriculture looks very promising. New lands and west Delta are important areas for this protected agriculture

Table (10): Results of sensitivity of green houses that produce cucumber, pepper and green beans.

\begin{tabular}{|c|c|c|c|c|c|}
\hline \multicolumn{2}{|l|}{ Statement } & Unit & Cucumber & Pepper & $\begin{array}{l}\text { Green } \\
\text { Beans }\end{array}$ \\
\hline \multirow{3}{*}{ Raising costs by $20 \%$} & NPV & (Thousand LE) & 17.26 & 74.74 & 17.57 \\
\hline & $\mathrm{B} / \mathrm{C}$ & (Ratio) & 1.70 & 3.90 & 1.67 \\
\hline & IRR & $(\%)$ & 70 & 238 & 71 \\
\hline \multirow{3}{*}{ Raising costs by $\mathbf{4 0 \%}$} & NPV & (Thousand LE) & 13.17 & 70.45 & 13.17 \\
\hline & $\mathrm{B} / \mathrm{C}$ & (Ratio) & 1.46 & 3.34 & 1.43 \\
\hline & IRR & $(\%)$ & 51 & 196 & 51 \\
\hline \multirow{3}{*}{ Raising costs by $60 \%$} & NPV & (Thousand LE) & 9.08 & 66.15 & 8.77 \\
\hline & $\mathrm{B} / \mathrm{C}$ & (Ratio) & 1.28 & 2.92 & 1.25 \\
\hline & IRR & $(\%)$ & 36 & 165 & 36 \\
\hline \multirow{3}{*}{ Returns decline by $20 \%$} & NPV & (Thousand LE) & 12.99 & 58.93 & 13.18 \\
\hline & $\mathbf{B} / \mathbf{C}$ & (Ratio) & 1.64 & 3.74 & 1.60 \\
\hline & IRR & $(\%)$ & 64 & 226 & 65 \\
\hline \multirow{3}{*}{ Returns decline by $\mathbf{4 0 \%}$} & NPV & (Thousand LE) & 4.63 & 38.83 & 4.38 \\
\hline & $\mathrm{B} / \mathrm{C}$ & (Ratio) & 1.23 & 2.81 & 1.20 \\
\hline & IRR & $(\%)$ & 32 & 156 & 31 \\
\hline \multirow{3}{*}{$\begin{array}{l}\text { Raising costs and returns } \\
\text { decline by } 20 \%\end{array}$} & NPV & (Thousand LE) & 8.90 & 54.64 & 8.77 \\
\hline & $\mathrm{B} / \mathrm{C}$ & (Ratio) & 1.36 & 3.12 & 1.33 \\
\hline & IRR & $(\%)$ & 43 & 180 & 43 \\
\hline \multirow{3}{*}{$\begin{array}{l}\text { Raising costs and returns } \\
\text { decline by } 30 \%\end{array}$} & NPV & (Thousand LE) & 2.68 & 42.44 & 2.18 \\
\hline & $\mathrm{B} / \mathrm{C}$ & (Ratio) & 1.10 & 2.52 & 1.08 \\
\hline & IRR & $(\%)$ & 21 & 135 & 19 \\
\hline
\end{tabular}

Source: results of the analysis by Cost Ben Program based on Tables (6-9) .

\section{Summary \& Recommendations}

Food gap in Egypt is attributed to the annual rising rate of population. There is an increasing wide gap between food supply and food especially plastic houses. Much hope is held to this modern technique to improve strongly production and productivity of most crops. 
The objectives of this research were to study the economics of green houses, through identifying constraints of production capacity and economic efficiency in Egypt in general and studying the targeted vegetables crops in particular. It also targeted the financial assessment of these houses. The research also covered cost and return and sensitivity to the dominant risks. This research relied on descriptive and quantitive economic analyses by using mathematic models from the perspective of the World Bank rules. The research was based on published secondary data from official establishments such as Ministry of Agriculture and CAPMAS. It also depended on data compiled from a form of random sample of about 130 green houses in Bahariya Oasises in 2014. It used sampling fraction about $3 \%$ of cucumber, pepper and green beans houses with of 50,40 and 40 houses respectively. Some references and subject related studies were also reviewed.

The findings indicate that the number of green houses accommodating crops of cucumber, pepper and green beans reached about 36.47 thousand houses with comparative importance estimated by about $90.90 \%$ of the total houses in Egypt. Cucumber occupied the first position with 21.54 thousand houses. Pepper came next to cucumber with about 8.04 thousands and green beans with about 6.89 thousand houses. Comparative importance of the three crops was $35.69 \%, 20.04 \%$ and $17.17 \%$, respectively. Total production of plastic houses increased significantly by about 15.90 thousand tons during 2000-2012.

The findings also show a significant increase in the number of green houses reached to about $2.24,1.18$ and 0.44 thousands annually during the period of this study. There is also a significant increase in the production of houses reaching about 7.39, 6.07 and 1.76 thousand tons per year during the period of the study.

Production efficiency of the houses was significantly higher than that of traditional agriculture for the three crops, (cucumber, pepper and green beans). Productivity of the three crops were higher by about $349.24 \%$ $350.29 \%$ and $248.46 \%$ respectively. Higher productivity of green house is simply attributed to providing better conditions such as temperature, moisture and ventilation plus relevant fertilizers and pesticides.
Financial analysis reveals that all crops targeted by this study achieved production efficiency as profit gained was bigger than opportunity cost. Most profitable crop was pepper then green beans then cucumber. IRR of the three crops were 295\%, 97\% and 95\% respectively.

\section{Recommendations}

* Inject more investment into protected agriculture as IRR is higher than $90 \%$ for green houses.

* Much emphasis should be placed on conducting intensive studies and researches to improve economic production and marketing efficiency and open new markets to absorb production of green houses and organic products.

* Strengthen coordination between projects and agricultural extension services of Ministry of Agriculture.

* More attention should be addressed to environmental assessment process to find out any risk might appear as a result of adoption protected agriculture technique.

\section{REFERENCES}

Central Agency for Public Mobilization and Statistics (CAPMAS), Statistical Year Book, various issues. (2000-2012).

El Abbasy H., Ahmed F., Abdel Aziz A. and Mervat A. (2014). Financial viability assessment of a 100 Feddan Area Farm at region to export vegetable crops, Minufiya J. of Agric. Res., Vol. (39), No. (5): October. 1763-1776.

El Abbasy H., and Zaki A. A. (2008). An economic analysis for feasibility study of cut flowers project for export in Egypt. Egyp. Jour. of Agric. Econ., Vol. (18), No. (4), December. 1062-1063.

Hassan A. and Mahmoud M. (2009). Analytical study of honey bee production and its economic feasibility in Sohag Governorate. Egypt. Jour. of Agric. Econ., Vol. (19), No. (2), June.

Korayem E. H. and Arram S. A. (2010). Analytical economic study for the production of the most important vegetable crops in the green houses on Sharkia Governorate, Egypt. Jour. of Agric. Econ., Vol. (20), No. (1), March.

Ministry of Agriculture and Land Reclamation, Central Department for Economic Affairs, Bull. The Agric. Statistics, various issues. 


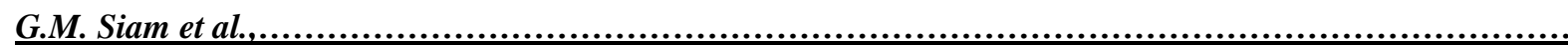

$$
\begin{aligned}
& \text { إقتصاديات الصوب الزراعية لأهم محاصيل الخضر في الأراضي الجديدة } \\
& \text { جمال محمد صيام ـ أشرف محمد شاهين أبو الريش* ـ عصام صبري سليمان علي* } \\
& \text { كلية الزر اعة - جامعة القاهرة ـ *قسم الدراسات الإقتصادية ـ مركز بحوث الصحر اء }
\end{aligned}
$$

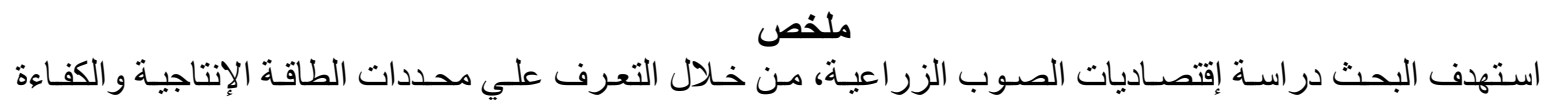

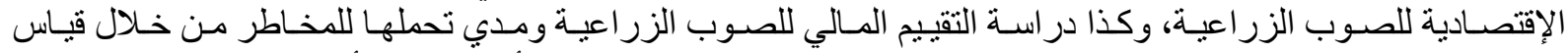

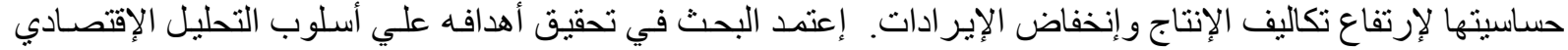

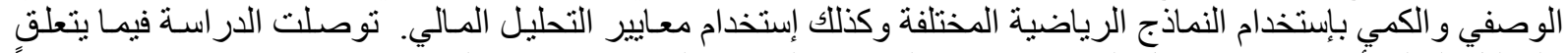

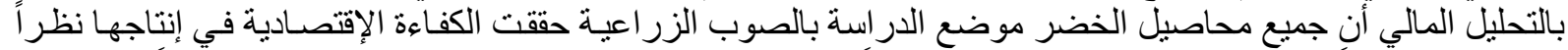

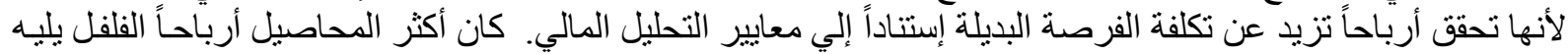

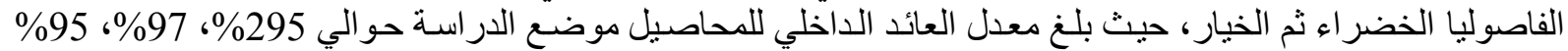

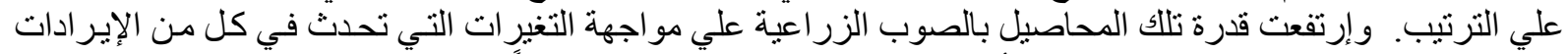

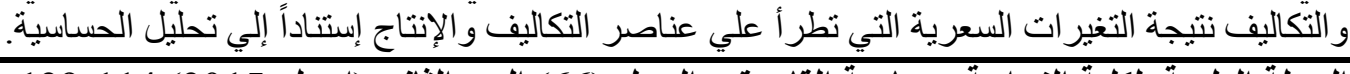

المجلة العلمية لكلية الزراعة - جامعة القاهرة - المجلد (66) العدد الثاني (إبريل 2015) 114-129. 